\title{
KARST RESEARCH IN SERBIA \\ BEFORE THE TIME OF JOVAN CVIJIĆ
}

\section{RAZISKAVE KRASA V SRBIJI PRED JOVANOM CVIJIĆEM}

\author{
Jelena ĆALIĆ ${ }^{1}$
}

\begin{abstract}
UDC 551.44(497.11)(091)"18/19"

Jelena Calić: Karst research in Serbia before the time of Jovan Cvijić

Although contributions by Jovan Cvijić are the most significant karstological work in the history of science in Serbia, the researchers of Serbian karst before the time of Cvijić are worth mentioning as well. Their karstological notes are usually parts of much more extensive works in the form of travel-records or landscape monographs. Most notes are related to caves, with only scarce mentioning of karst surface features. The descriptive character of the texts is dominant, although there are also some general remarks on hydrological functioning of karst (ponor-spring connections, role of water in formation of speleothem, etc.). Several authors can be singled out: foreign travellers and scientists Otto von Pirch, Ami Boué and Felix Kanitz, while among the Serbian authors, it is necessary to mention Milan Đ. Milićević, Jovan Žujović and Cvijić’s teacher Vladimir Karić. All of them featured as an introduction to the scientific karstological work which followed at the end of the $19^{\text {th }}$ and the beginning of the $20^{\text {th }}$ century.
\end{abstract}

Key words: history of karstology, $19^{\text {th }}$ century, pre-Cvijić, Serbia.

\begin{abstract}
Izvleček
UDK 551.44(497.11)(091)"18/19" Jelena Ćalić: Raziskave krasa $v$ Srbiji pred Jovanom Cvijićem Čeprav je Cvijićev prispevek h krasoslovju najpomembnejši v zgodovini znanosti v Srbiji, so raziskovalci srbskega krasa pred Cvijićevim časom tudi vredni omembe. Njihovi zapisi o krasu so običajno vključeni v veliko obsežnejša dela v obliki potopisov ali pokrajinskih monografij. Večina the omemb se nanaša na jame z zelo skopimi omembami kraških površinskih oblik. $\mathrm{V}$ the besedilih prevladuje opisni značaj, čeprav je tudi nekaj omemb glede hidrološkega delovanja krasa (zveze med ponori in izviri, vloga vode pri nastajanju kapnikov, itd.). Nekaj avtorjev je treba posebej poudariti: tuje popotnike in znanstvenike, kot so Otto von Pirch, Ami Boué in Felix Kanitz, medtem ko so med srbskimi avtorji posebej vredni omembe Milan Đ. Milićević, Jovan Žujović in Cvijićev učitelj Vladimir Karić. Vsi navedeni so predhodniki znanstvenega krasoslovnega dela, ki se je pričelo konec 19. in v začetku 20. stoletja.

Ključne besede: zgodovina krasoslovja, 19. stoletje, čas pred Cvijićem, Srbija.
\end{abstract}

\section{INTRODUCTION}

Whenever karst research in Serbia is mentioned, the first association is always Jovan Cvijić (1865-1927), who is worldwide considered a founder of scientific karstology thanks to his major work "Das Karstphänomen" (1893). The year 1887 can be taken as a start of Cvijićs explorations of Serbian karst: he published his first scientific paper, dealing with geographical terminology (Cvijić 1887), in which karst terms were presented to a significant ex- tent. In 1889 he published his first paper related particularly to karst relief in Eastern Serbia (Cvijić 1889).

Speaking about any geographical research in Serbia before the time of Cvijić, it is necessary to point to some historical circumstances. From 1459 to 1878, Serbia was constantly under the rigid government of the Ottoman empire. The life of ordinary people was marked with utter poverty and permanent assaults by the occupation army,

\footnotetext{
${ }^{1}$ Geographical Institute "Jovan Cvijić" of the Serbian Academy of Sciences and Arts, Đure Jakšića 9, 11000 Belgrade, Serbia; e-mail: j.calic@sezampro.yu
}

Received/Prejeto: 21.11.2006 
while the educational system was practically forbidden. There were no schools or universities, and consequently, no conditions for any scientific work. Scarce records on geographical and geological characteristics were made by foreign travellers, like Otto von Pirch (1830) and Ami Boué (1840), while the first Serbian travel-records appeared also in the first half of the $19^{\text {th }}$ century, when Serbia started to obtain some elements of autonomy. These were the travel records by the linguist and ethnologist Vuk Karadžić (1826) and the writer Joakim Vujić (travels from 1826, published in Serbia in 1901 and 1902). It must be stressed that pre-Cvijić notes on Serbian karst were mostly of descriptive character, just with some fragments of general conclusions on functioning of karst, but without the complex elements of scientific studies. Most of the descriptions were related to caves, due to the fact that extensive karst surface phenomena occur only on remote locations that were very scarcely populated, and generally out of the routes of travellers.

\section{OVERVIEW OF MOST SIGNIFICANT CONTRIBUTIONS}

Vuk Karadžić (1826) made a brief mention of Turčinovac Cave in his descriptions of monasteries in the gorge of the Zapadna Morava River. That is the oldest written reference about any cave in Serbia. A number of monasteries dating from $14^{\text {th }}$ to $19^{\text {th }}$ century were built in isolated gorges and caves, in order to be hidden from the Turks.

A more lengthy description of several caves was given by Vujić in his 1826 travel-records $(1901,1902)$. Vujić did not use the term "pećina", which is the usual Serbian word for "cave", but the words "peščera" and "grota". It is obvious from the descriptions that he did not enter any of these caves, but only made some observations at the entrances, with notations of local legends, and attributes like "horrifying", "frightful", "dark". Vujić mentioned the cave entrances in Gornjak gorge, the cave Ravanička Pećina, as well as the cave Petnička Pećina in western Serbia, in which he correctly noticed the intermittent character of the outflowing stream Banja.

A Prussian officer Otto Ferdinand von Pirch travelled through Serbia in the year 1829 and published a book about that in Berlin in 1830 (Serbian translation of this book was published in Belgrade in 1899). Apart from the caves in Gornjak gorge, and the cave Ravanička Pećina, he also mentioned the caves by the town of Golubac (Pećine Golubačke Mušice), at the entrance to the Danube gorge. Pirch's descriptions are much more realistic and objective than those of Vujić, containing also some details about perceptions and/or usage of caves by the local population (e.g. during the winter, shepherds lodged the goats in caves; monks from Ravanica monastery went with torches into the cave Ravanička Pećina for 3-4 hours; etc.).

Probably the best pre-Cvijić notes on some caves in Serbia were given by the French/Austrian geologist Ami Boué $(1840,1891)$, during his geological explorations of so-called "European Turkey". Like Pirch, Boué visited the caves in the Gornjak gorge, the cave Ravanička Pećina and the caves in the Danube gorge, but also the ice-cave Ledenica on Mt.Rtanj, where he measured the air temperature at the bottom. As he visited a great number of caves on the whole Balkan peninsula, he made some conclusions about their genesis: "Most of the great caves are nothing else but remnants of old underground water courses, while more shallow caves are caused by partial decomposition of rocks, with an influence of bedding". Boué also noticed occurences of karst surface relief: "Rocky surfaces full of dolines, like in Lower Carinthia, occur in the area of Turkish Croatia; in the surroundings of Valjevo in Serbia; between Sijatista and Kožan in Macedonia.... There is also an interesting remark about relation between surface and underground morphology: "In Cretaceous limestones, natural shafts are also frequent, although they are rarely so nicely characterized as in the case of Ledenica, in the woods on the southern slopes of Mt. Rtanj. Dolines or "kombi", that mainly occur on limestone plateaus, are nothing else but similar shafts or fissures, through which waters sank for a long time, until finally breakdowns occurred due to prolonged erosion." (Boué 1891).

Another foreign traveller who made a lot of notes on karst forms in Serbia was Felix Kanitz. He made a number of travels through Serbia during more than 30 years (from 1856 to 1899), searching mainly for archeological remains of Greek and Roman civilizations. However, his studies were much more than that: in two large volumes of travel-records (published in 1909), he made precious and wise observations of natural and social characteristics of $19^{\text {th }}$ century Serbia. Kanitz's descriptions of natural phenomena abound in interesting details and comparisons, and there is a noticeable tendency towards scientific, problem-solving approach. He visited many more caves than the previous travellers, and paid considerable attention to surface karst morphology as well. In the cave 
Prekonoška Pećina, he visited even the most distant passages and chambers: "The Third chamber, which can be entered only using the rope, contains beautiful cave decoration, that reminds of Adelsberg, and of a coupola building with countless pillars, altars, chandeliers, etc. In side passages there are conspicuously big stalactites as well, and in all passages there are remnants of extinct animal species." Writing about Mt.Kučaj, Kanitz observed: "Its high plateaus, that incessantly extend towards the east, are rich in small streams, that usually end in funnel-shaped ponors, and through deep bottoms of dolines, sink into lower permeable layers of limestone. (...) A bit further towards the north-east, surrounded by 40 smaller dolines, there is a $250 \mathrm{~m}$ long doline Brezovica, with steeply cut edges and a $120 \mathrm{~m}$ long stream that sinks into a deep abyss."

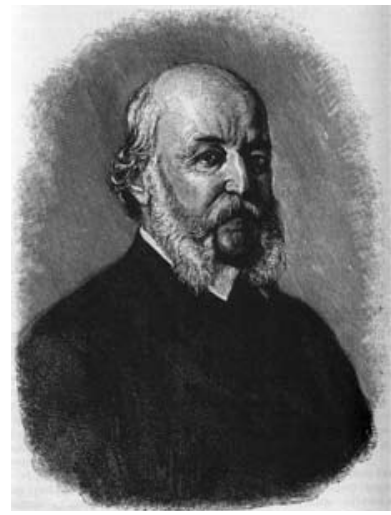

Felix Kanitz

(1872), in which there are valuable observations about small karst areas in central Serbia (Šumadija region, around Mt.Rudnik), where limestones are rather rare. Writing about the cave Vodena Pećina, he stresses the importance of geological composition, and notices cave biota as well: "Vodena Pećina is the real and the main spring of Čemernica River. (...) In the cave, there are lots of bats. It is dark and one cannot make even 10 steps without the light. The rocks are of lime formation, as well as all the surroundings, and that is why it is characterized by numerous caves..." Regarding the karst spring of Ljig River in the village $\mathrm{Ba}$, in the same region, Mišković wisely notices the difference between the outflow from Vodena Pećina (modern karstological term would be 'gravitational' outflow) and from the Ljig spring (siphonal uprising): "The spring of Ljig, as well as that of Čemernica, emerges from lime formation of rocks, from a cave (...). However, this spring varies from that of Čemernica, because here the water 'boils', comes from below... when something is dropped on that place, it sinks very deep, so it is obvious that this is a great abbyss, and that the water emerges from below (...). Sometimes the water is high, and then it is murky, carrying red soil. That is why it is believed that its head is in Dobro Polje, because such soil can be found there." (Mišković 1872).

Milan Đ. Milićević was a well-known Serbian intellectual from the second half of the $19^{\text {th }}$ century. His major work "Kneževina Srbija" ("Principality of Serbia") was published in 1876, just two years prior to Serbia's gaining of independence. This is the work of historical and geographical character, with abundance of valuable facts and data, although his descriptions sometimes have a kind of "romantic" approach, like in the case of the cave Prekonoška Pećina: "It is only the dripping water that interrupts, but very softly, this quiet silence, deep underground. And it is the water that makes these miracles that you admire in the cave". Apart from the descriptions of significant caves like Petnička Pećina, Prekonoška Pećina, Zlotska Pećina (mostly the same ones as the previously mentioned authors), Milićević pays particular attention to surface morphology, underground hydrological connections, and general functioning of karst (although he does not use that term). "People who live close to Mt.Rtanj, and who often climb its highest peak Šiljak, have noticed that sometimes some dolines, some holes plunge down on this mountain. Half joking, and half seriously, they say that Rtanj is dissolving, and that, by acting in that manner, it can lower so much that it will become like some usual hill". One of the interesting karst phenomena, a deep siphonal spring of the Mlava River in the village of Žagubica in Eastern Serbia, occupied the attention of Milićević as well: "It cannot be said for sure where the water of this spring comes from; but people from Žagubica have noticed that this spring always becomes muddy when there is a heavy rain on Mt. Beljanica (south from Homolje). However, when it rains on Crni Vrh, Mlava flows as usually". Apart from the spring Banja, which flows out of the cave Petnička Pećina, Milićević describes one more intermittent spring - Potajnica in the region of Zvižd in Eastern Serbia. Potajnica is not only a toponyme, but also a Serbian term for intermittent spring. "Potajnica in Zvižd, half an hour below Kruševica, on the right bank of the Pek River. Potajnica is situated 5 hvats $^{1}$ above the Pek water surface, and 10 hvats away from the Pek. It is in lime rocks. People say that it fills with water 5,6 or 10 times a day, and then empties itself again; water sinks somewhere between the rocks, and when that happens, one can hear some noise, like a drum, like a roar of stones, or a blow of wind". When describing probably the most extensive karst area in Eastern Serbia, the section from the Danube to Mt.Rtanj, Milićević draws some conclusions: "It happens that very strong and abundant

\footnotetext{
${ }^{1}$ Hvat, an old measure for length. 1 hvat $=6$ feet
} 
streams sink into some doline, or a heavy rain rushes into some echoing hole ("zvečara"), and it is considered that this water resurges afterwards, far away, as a new spring. This can also be the case of the springs of Mlava and Krupaja" (Milićević 1876).

One of the most important persons for the whole history of karst research in Serbia is definitely Vladimir Karić. His direct influence is reflected through a capital book "Serbia", published in 1887, with detailed descriptions of natural (and other) characteristics of Serbia, including karst phenomena. Karićs indirect influence on karst research in Serbia and on karstology as a scientific discipline is the fact that he was a secondary-school teacher of Jovan Cvijić, and actually the one who persuaded Cvijić to enroll the studies of geography.

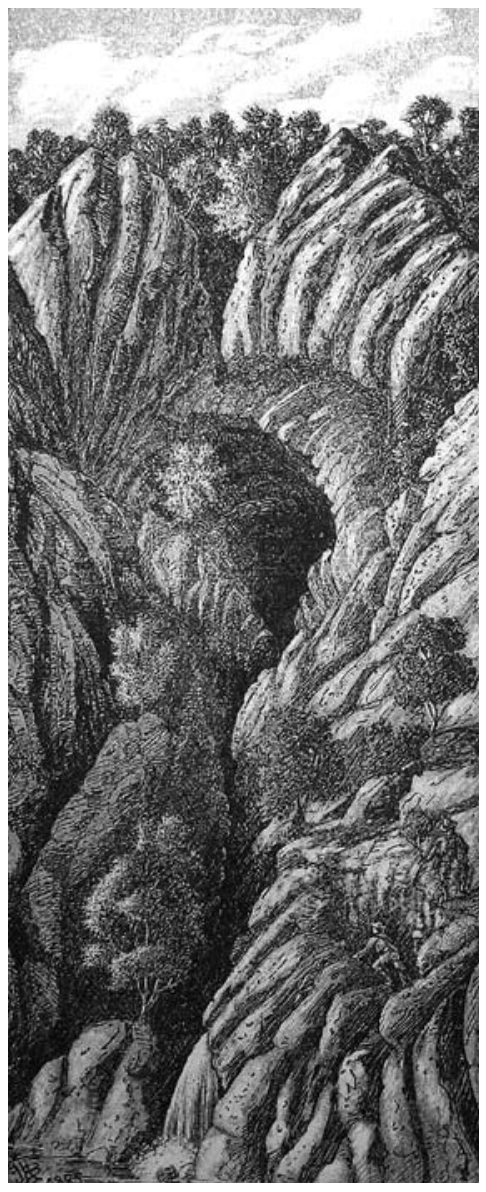

Entrance to the cave Dubocka Pećina (sketch by Vladimir Karić, 1887) popularly called $v i$ gled." Vigled means 'daylight hole' or 'cave ceiling window', and that term is still in regular use in Serbian karstological literature.
In his extensive chapter on the cave Prekonoška Pećina, as well as in descriptions of some other caves, he uses the term "kapnik"2 for calcite speleothem (kapnik is presently used only in Slovenian language, not in Serbian): "After entering the cave, there is immediately the brightness of snow-white pendants ${ }^{2}$ consisting of kapnik stone, that hang from the ceiling, or grow from the floor, or the two are finally connected to each other and resemble marble columns. The floor is white as well, because it is also coated in tufa kapnik. Going a bit farther, pendants are no longer present, the floor becomes clayey, while the high ceiling is black of numerous bats, that have hidden there and have attached to the rock. Below the clay, there are bones of cave bears, and maybe also of some other extinct animals, as well as some remnants of clay dishes, formerly used by men - previous inhabitant of these caves". In the cave Zlotska Pećina (also called Lazareva), there were also observations of speleothem: "At the beginning, only dripping of water can be heard. Only somewhere, pendants of kapnik rock can be seen, created by water, little by little through the centuries, seeping through lime cave ceilings and dripping on the floor".

Within Karićs book "Serbia", there is a chapter related to geological composition, written by the founder of Serbian geology, Jovan Žujović. In this chapter (as well as in some of his papers, like the one published in 1889), Žujović gives his opinions on cave genesis and functioning of karst: "In limestone areas, the water carved numerous, big, often very branching caves, in which sometimes the remains of ancient animals and men can be found. In this respect, the most interesting caves are Zlotska, Prekonoška and Petnička. Water in these areas, captured in dolines, cannot flow across the surface, but descends through the fissures to the depth, where in the network of favourable conduits it collects into underground rivers that emerge to surface as springs, with huge amounts of water".

\footnotetext{
${ }^{2}$ The word used in the original text is ledenica, meaning "ice pendant", but it did not remain as a term, because it stands for a genetically different feature.
} 


\section{CONCLUSION}

It can be concluded that the observations of Vladimir Karić, together with the geological comments of Jovan Žujović, represent the cross-section through the state of karst research in Serbia before the capital works of Jovan Cvijić. However, all the mentioned authors have contrib- uted to a significant extent to the basic notions on Serbian karst, and play their role, as a historical background, in the scientific approaches which followed afterwards, in the $20^{\text {th }}$ century.

\section{REFERENCES}

Boué, A., 1840: La Turkie d'Europe.- Paris

Boué, A., 1891: Geološka skica evropske Turske (In Serbian; Geological sketch of European Turkey).Translation from French by Jovan Cvijić and Jovan Žujović. Geološki anali balkanskog poluostrva, vol. III, Beograd

Cvijić, J., 1887: Prilog geografskoj terminologiji našoj (In Serbian; Contribution to our geographical terminology).- Prosvetni glasnik; Decembar 1887, p.903916, Januar 1888, p.18-21, Beograd

Cvijić, J., 1889: Ka poznavanju krša Istočne Srbije (In Serbian; Towards the notion of karst of Eastern Serbia).- Prosvetni glasnik; Januar, p.1-18, Februar, p.62-73, Mart, p.131-139, Beograd

Cvijić, J., 1893: Das Karstphänomen. Versuch einer morphologischen Monographie.- Geographische Abhandlungen, Bd. V. Heft. 3, p.1-114, Wien

Kanitz, F., 1909: Das Königreich Serbien und Das Serbenvolk, von der Römerzeit bis zur Gegenwart. Zweiter band, Land und Bevölkerung.- Verlag von Bernh. Meyer, Leipzig (Serbian translation: Feliks Kanic: Srbija. Zemlja i stanovništvo - od rimskog doba do kraja XIX veka. Druga knjiga.- Srpska književna zadruga \& IRO Rad, Beograd 1985)

Karadžić, V., 1826: Početak opisanija srpski namastira (In Serbian; Start of descriptions of Serbian monasteries).- Sabrana dela V. Karadžića, vol. VIII: "Danica” za 1826, 1827, 1828, 1829, 1834; Priredio Milorad Pavić, p. 920+2, Prosveta, Beograd 1969.

Karić, V., 1887: Srbija. Opis zemlje, naroda i države (In Serbian; Serbia. Description of land, people and the state).- Kraljevsko-srpska državna štamparija, p. 935, Beograd
Mačaj, S., 1892: Crnorečki okrug (In Serbian; Crnorečki region).- Glasnik Srpskog učenog društva, 73, Beograd

Milićević, M.Đ., 1876: Kneževina Srbija (In Serbian; Principality of Serbia).- Državna štamparija, Beograd

Mišković, J., 1872: Opis Rudničkog okruga (In Serbian; Description of Rudnik region).- Glasnik Srpskog učenog društva, 34, Beograd

Petrović, D., 1988: Istorija srpske speleologije (In Serbian; History of Serbian speleology).- Posebna izdanja Srpskog geografskog društva, 66 (p. 1-119); Beograd

Pirch, O. F., 1830: Reise in Serbien in Spaetherbst 1829.Berlin bei Ferdinand Dümmler, p. $8+276+2$, Berlin. (Serbian translation: Pirh, Oto Dubislav plem.: Putovanje po Srbiji u godini 1829. Srpski prevod Dragiše J. Mijuškovića. Srpska kraljevska akademija, p. VI+247, Beograd 1899

Vujić, J., 1901: Putešestvije po Serbiji I (In Serbian; Travels through Serbia I).- Srpska književna zadruga, Beograd

Vujić, J., 1902: Putešestvije po Serbiji II (In Serbian; Travels through Serbia II).- Srpska književna zadruga, Beograd

Žujović, J., 1889: Osnovi za geologiju Kraljevine Srbije (In Serbian; Basics for the geology of the Kingdom of Serbia).- Geološki anali Balkanskog poluostrva, vol. I, Beograd 
